\title{
MKNK2 Gene
}

National Cancer Institute

\section{Source}

National Cancer Institute. MKNK2 Gene. NCI Thesaurus. Code $C 91864$.

This gene is involved in the phosphorylation of proteins. 